\title{
İlköğretim Din Kültürü ve Ahlak Bilgisi Dersi Öğretim Programı'nın Kültürlerarası Din Eğitimi Açısından Değerlendirilmesi
}

\author{
Evaluation of Primary Education Religious Culture and Moral Knowledge Course \\ Curriculum in Terms of Intercultural Religious Education
}

\author{
Nazım BAYRAKDAR ${ }^{1}$ \\ Halil İbrahim AKSU²
}

\author{
Araștırma Makalesi / Research Article \\ Geliş Tarihi / Received: 11.05.2021 \\ Kabul Tarihi / Accepted: 25.06.2021 \\ Doi: $10.48146 /$ odusobiad.936074
}

\begin{abstract}
Atıf /Citation: Bayraktar, N. ve Aksu, H.B., "Illköğretim Din Kültürü ve Ahlak Bilgisi Dersi Öğretim Programı'nın Kültürlerarası Din Eğitimi Açısından Değerlendirilmesi”, ODÜSOBIAD 11(2),563-580, doi: 10.48146/odusobiad.936074
\end{abstract}

\begin{abstract}
Öz
Ülkemizde 1982 Anayasası'nın ilgili maddesi gereğince din dersleri ilköğretim ve ortaöğretim kurumlarında zorunlu olarak okutulmaktadır. Halkımızın kahir ekseriyeti zorunlu din dersi uygulamasından memnun olmakla birlikte ülkemizde bu uygulamadan rahatsızlık duyan kesimler de mevcuttur. Nitekim zorunlu din dersine yönelik itirazlar çeşitli platformlarda dile getirilmeye devam etmektedir. Çocuğunun zorunlu din dersinden muaf olması için ulusal ve hatta uluslararası hukuk yollarına başvuran vatandaşlarımızın varlığı, zorunlu din dersinden duyulan rahatsızlığın büyüklüğünü göstermektedir. Bu rahatsızlığın görmezden gelinmesi ne kadar yanlış ise bu rahatsızlık gerekçe gösterilerek zorunlu din dersi uygulamasından vazgeçilmesi de o kadar yanlıș olacaktır. Bu noktada yapılması gereken, meselenin bilimsel yaklaşım temelinde ele alınmasıdır. Din eğitimi gibi hassas bir alanda sağlıklı düzenlemeler yapılması ve dinin toplumda ayrıștırma değil, birleștirme ișlevinin ön plana çıkarılması açısından bilimsel yaklaşım son derece önemlidir. Bu çalışma, halen yürürlükte olan İlköğretim Din Kültürü ve Ahlak Bilgisi Dersi (DKAB) Öğretim Programı'nın kültürlerarası din eğitimi açısından değerlendirilmesi maksadıyla yapılmıștır. Çalıșmada, kültürlerarası din eğitimi, DKAB dersi için yapılacak program geliştirme çalışmalarında model alınması değil, yararlanılması gereken bir yaklaşım olarak ele alınmıştır. Araştırmada, doküman analizi yöntemi kullanılmıştır. Araştırma sürecinde elde edilen veriler, öğretim programının genel hedefleri ile vizyonunun kültürlerarası din eğitimi yaklaşımıyla gayet uyumlu olduğunu göstermektedir. Ancak genel amaçlar ile vizyonun içeriğe ve kazanımlara yeterince yansımadığı görülmüștür. Programda İslam dıșındaki dinlerin tanıtıldığı müstakil bir üniteye rastlanmamıștır. İslam düşüncesindeki yorum farklılıklarını tanıtıcı nitelikte bilgilere ise sadece bir ünitenin ayrıldığı tespit edilmiştir. Toplumun farklı kesimleri açısından hassasiyet arz eden meselelerde normatif ifadelere yer verilmeyip betimleyici bir dilin tercih edilmiș olması öğretim programının kültürlerarası din eğitimi açısından olumlu yönlerinden birini oluşturmaktadır. Programda, İslam dininin belirli bir yorumunun ön plana çıkarıldığı iddiasını haklı çıkaracak unsurlara da rastlanmamıștır. Toplumdaki çoğulluk olgusundan kaynaklanan hassasiyetler gözetilerek hazırlandığı açık olsa da bu hassasiyetin eğitim sürecinde DKAB öğretmenlerinin davranışlarına nasıl yansıması gerektiği hususunun programda yeterince netliğe kavuşturulmadığı görülmüștür.
\end{abstract}

Anahtar Kelimeler: Çoğulculuk, çok kültürlülük, kültürlerarası eğitim, kültürlerarası din eğitimi, zorunlu din dersi, öğretim programı.

\begin{abstract}
In accordance with the relevant article of the 1982 Constitution, religion courses are compulsory in primary and secondary education institutions in our country. While the vast majority of our people are satisfied with the compulsory religion lesson there are also some people in our country who are uncomfortable with this practice. As a matter of fact, these segments continue voicing their objections to the compulsory religion course on various platforms. The existence of our citizens who have turned to national and even international legal remedies in order for their children to be exempt from compulsory religion lessons clearly shows the magnitude of the discomfort felt from compulsory religion lessons. If it is wrong to ignore this discomfort, it will be wrong to give up the compulsory
\end{abstract}

1 Sorumlu yazar, Doç. Dr., Ușak Üniversitesi İslami İlimler Fakültesi, Ușak, e-mail:, nazim.bayrakdar@usak.edu.tr, ORCID ID: 0000-0002-5500-5170.

2 Okul Müdürü, Milli Eğitim Bakanlı̆̆ı, Hatay, e-mail: hiaksu@hotmail.com, ORCID ID: 0000-0003-2455-7455. 
religion lesson on the grounds of this discomfort. At this point, what needs to be done is to deal with the issue on the basis of a scientific approach. The scientific approach is extremely important in terms of ensuring that the regulations to be made in a sensitive area such as religious education are healthy and that the function of religion in society is to be united rather than separated. This study was carried out in order to evaluate the Primary Education Religious Culture and Moral Knowledge Lesson Curriculum which is still in effect in terms of intercultural religious education. The study was conducted with the assumption that intercultural religious education is an approach that should be utilized not taken as a model in program development studies for the Religious Culture and Moral Knowledge course. Data were collected by document analysis method. The data obtained during the research process show that the general objectives and vision of the curriculum are very compatible with the intercultural religious education approach. However, it has been observed that the vision with general purposes is not sufficiently reflected in the unit outcomes.

Keywords: Pluralism, multiculturalism, intercultural education, intercultural religious education, compulsory religion course, teaching program.

\section{Giriş}

Din eğitimi, insanlıkla yaşıt bir faaliyettir. Bu faaliyetin nasıl bir anlayışla, hangi amaçlar doğrultusunda, kimler tarafından, nerede ve nasıl yürütüleceği hususunda tarihsel süreçte farklı yaklaşımlar ortaya çıkmıştır. Etkisi altında kaldıkları çeşitli faktörlere bağlı olarak toplumlar din eğitimi meselesine yönelik yaklaşımlarını sürekli gözden geçirmek durumunda kalmışlardır. Bu faktörler arasında son dönemde en belirleyici olan ise küreselleşme olgusuna bağlı olarak ortaya çıkan riskler ve ihtiyaçlar olmuştur.

Özellikle II. Dünya Savașı'ndan sonra bir yandan köyden kente diğer yandan ise gelişmemiş ülkelerden gelişmiş ülkelere göç eden insanların oranında ciddi bir artış yaşanmıştır. Yine bu dönemde bilim ve teknoloji alanında meydana gelen hızlı gelişmeler iletişim ve ulaşım alanlarında yeni imkânları ortaya çıkarmış ve buna bağlı olarak da toplumlar ve kültürler arasındaki sınırlar adeta ortadan kalkmıştır (Sancak, 2015; Altaş, 2003). Dili, dini, din anlayışı, ideolojisi, siyasi görüşü, hayat anlayışı ve yaşam tarzı farklı olan kişilerin birbirleri ile karşılaşma ve etkileşim kurma ihtimalinin artması gerek insan hakları ve gerekse toplumsal barış açısından birtakım riskleri beraberinde getirmiş; kültürlerarası etkileşim sürecinin yönetilmesini zorunlu kılmıştır. $\mathrm{Bu}$ zorunluluk uluslararası kurum ve kuruluşları taraf devletlerle ve bilim insanlarıyla işbirliği yaparak çözüm geliştirmeye yöneltmiştir. İște bu süreçte ortaya atılan ve son dönemde sıkça tartışma konusu yapılan çözüm yollarından biri 'kültürlerarası eğitim' olmuştur (Aydın ve Osmanoğlu, 2015).

Kültürlerarası eğitim kavramı, kültürler arasındaki mevcut ya da muhtemel gerginlikleri ve önyargıları azaltmak, bir ülkede ya da bölgede yaşayan insan topluluklarının ortak yaşama tam olarak katılmalarını sağlamak amacıyla düzenlenen eğitim, şeklinde tanımlanmaktadır (Oğuzkan, 1993). Bu tanım amaç odaklı olup kültürlerarası eğitim faaliyetleriyle ulaşılmak istenen temel hedefleri belirtmektedir. Literatürde, kültürler arası eğitimin nasıl bir süreç olduğunu belirten tanımlamalara da rastlanmaktadır. Tumat (1992)'a ait şu tanımlama buna örnek olarak verilebilir. "Kültürlerarası eğitim; kültürlerin eşitliği, eşdeğerliliği, hoşgörü, çoğunluğun ve azınlığın birbirlerini anlamaya hazır olmaları gibi anlayış ve değerler üzerine inşa edilen karşılıklı bir süreçtir (Akt. Coşkun, 2016).

Kültürlerarası eğitimde aslolan dil, din, ırk, cinsiyet, sosyal sınıf vb. farklılıkların zenginlik olarak kabul edildiği ortamlarda bireylerin ötekileştirilmeye maruz kalmadan farklılıkları doğru şekilde tanımalarına ve farklı olarak gördükleri kişilerle sağlıklı ilişkiler kurmalarına katkı sağlamaktır. Kültürlerarası eğitimde, kültürel çeşitlilik mutlaka korunması gereken bir değer olarak görülürken tek tipleştirici uygulamalara karşı çıkılır. Eğitimde fırsat eşitliği, çoğulculuk, demokratik yaklaşım, eleştirel düşünme, empati, gruplar/sınıflar arası işbirliği ve toplumsal barış kültürlerarası eğitimi tanımlamak için sıkça kullanılan kavramlardır (Topcubaşı, 2016).

Kültürlerarası eğitimin, kültürel homojenleşmeyi sağlama gibi bir amacı bulunmamaktadır. Zira kültürlerarası eğitim, bir toplumdaki tüm bireylerin kendi kültürlerini terk etmeden bașka kültürleri de öğrenmelerini ve onlara saygı duymalarını öngörmektedir (Okumuşlar ve Bilecik, 2019). Azınlık ya da göçmen olarak nitelendirilen grupların çoğunluk tarafından asimile edilerek kendi kültürlerine yabancılaşmalarının önüne geçmek de kültürlerarası eğitimin hedefleri arasındadır (Nohl, 2009).

Kostova (2005), kültürlerarası eğitimin en temel amacının bireylere, farklı olarak gördükleri kişileri tanıma, anlama ve onlara karşı saygılı olma gibi davranışları kazandırmak olduğunu belirtmiştir. 
Farklı kültürlere mensup kişilerin birbirleriyle sağlıklı iletişim kurmalarını güçleştiren ön yargılardan kurtulmaları, birbirlerine yönelik sağlıklı bakış açısı geliștirmeleri ve nihayet küresel toplumun etkin bir üyesi haline gelmeleri de kültürlerarası eğitimin öncelikli hedefleri arasındadır. Bütün bunlar göstermektedir ki kültürlerarası eğitim, ötekine tahammülsüzlüğün tarihsel süreçte yol açtığı olumsuzluklara yenilerinin eklenmesine firsat vermemek üzere geliştirilen çözüm yollarından biridir.

Geleneksel okul kültüründe demokratik yaklaşım yeterince benimsenmediği için farklılıkları bir zenginlik olarak değil bir tehdit olarak görme, farklılıkları görmezden gelme ve farklı olanı ötekileştirme gibi davranışlara sıkça rastlanabilmekteydi (Kaya, 2018). Ancak son dönemde çeşitli faktörlerin etkisiyle toplumlarda söz konusu davranışlara karşı giderek yükselen bir tepki oluştu. Demokrasi, özgürlük, insan hakları gibi kavramlara gerek ulusal gerekse uluslararası düzeyde giderek daha fazla vurgu yapılmaya başlandı. Çoğulcu yaklaşımı savunanların oranı, toplumlarda giderek artmaya başladı. Eğitim alanının bütün bu gelişmelerden etkilenmemesi tabi ki düșünülemezdi. Kültürlerarası eğitim işte bu etkilenmenin en somut örneğini teşkil etmektedir (Altaş, 2001).

Birçok medeniyete beșiklik yapmıș bir coğrafya üzerinde yaşıyor olmamız, dili, dini, mezhebi, etnik kökeni farklı grupların öteden beri ülkemiz toprakları üzerinde bir arada yaşıyor olmaları, gerek eğitim gerekse çalışmak için uzun süreli olarak yurt dışına giden insan sayısının her geçen yıl artış göstermesi, ticari faaliyetlerin uluslararası boyut kazanması, Avrupa Birliği'ne uyum süreci vb. durumlar kültürlerarası eğitimi devletimizin kayıtsız kalabileceği bir alan olmaktan çıkarmıştır (Cırık, 2008; Küçük, 2011)). Nitekim ülkemizde 2000'li yılların başından itibaren kültürlerarası eğitimle hedeflenen kazanımlar öğretim programlarında daha fazla yer bulmaya başlamıștır.

Kültürlerarası eğitimin önemli bir parçasını, kültürlerarası din eğitimi oluşturmaktadır. Zira kültür içerisinde en baskın unsuru 'din' teşkil etmektedir. Kültürün hemen her parçasında dinin etkisini görmek mümkündür. Bu, kültürlerin oluşumunun dinin etkisi altında gelişen bir süreç olmasının kaçınılmaz bir sonucudur (Okumuş, 2016).

Tarihsel süreçte kültürel farklılıkların ayrışma ve çatışma sebebi haline gelmiş olması, birçok faktörün yanında dinin anlaşılma biçimi ile de yakından alakalıdır. Bu nedenledir ki din eğitimi alanı göz ardı edilerek kültürlerarası eğitim faaliyetlerinin amacına ulaşması mümkün değildir. 20. yüzyılın ikinci yarısından itibaren Avrupa devletlerinde kültürlerarası eğitime paralel şekilde kültürlerarası din eğitimine yönelik ilginin artmıș olması esasen bundan kaynaklanmaktadır.

Kültürlerarası din eğitimi; kültürlerarası bilgi, beceri ve tutumları farklı dinlerden ya da din içerisindeki farklı yorumlardan seçilen muhteva eşliğinde bireylere kazandırma sürecidir (Aydın ve Osmanoğlu, 2015). Kültürlerarası din eğitimi, din alanındaki farklı tercihlerin ve düşüncelerin saygıyla karşılanıp desteklendiği, kültürlerin eşit kabul edildiği, çoğunluğun ve azınlığın birbirlerini anlamaya hazır oldukları eğitim ortamları gerektirir (Öncel, 2013). Zira kültürlerarası din eğitiminin temel amacı, bireylerin dini tercihleri farklı olan kişilere ve toplumlara yönelik sağlıklı bir bakış açısı geliştirmelerine ve buna bağlı olarak da toplumsal ve küresel barışa katkı sağlamaktır. Bu amaca kini ve nefreti körükleyebilecek yaklaşımları terk edip empatiyi, saygıyı ve hoşgörüyü besleyen yaklaşımları esas alarak ulaşmak esastır (Ayas, 2020). Bu amaca ulaşmak aynı zamanda küresel düzeyde bir işbirliği gerektirdiği için uluslararası kurum ve kuruluşlar, taraf devletlerden din eğitimi hizmetlerini belirli ilkeleri esas alarak yapılandırmalarını istemektedir. İnsan Hakları Evrensel Beyannamesi, Avrupa İnsan Hakları Sözleşmesi, Birleşmiş Milletler Şartı buna örnek teşkil eden uluslararası hukuki metinlerden sadece birkaçını oluşturmaktadır. ${ }^{3}$ Program geliştirme sürecinde tek bir din ya da din anlayışının merkeze alınmaması; tarafsız, çoğulcu ve nesnel bir yaklaşımın esas alınması bu ilkelerden bazılarıdır (Aydın ve Osmanoğlu, 2015). Din dersinin bu ilkeler gözetilmeden zorunlu olarak okutulması uluslararası hukukta insan hakkı ihlali sayılmaktadır.

Din öğretimi hizmetleri için program hazırlanırken toplumdaki dinsel çeşitliliğin göz ardı edilmemesi, kültürlerarası din eğitimi açısından önemlidir. Ancak en az bunun kadar önemli olan bir başka husus, farklı din anlayışlarına ya da dini gruplara programda nasıl bir yaklaşımla yer verildiğidir. 0 kadar çeşitlilik içerisinde dinin belirli bir yorumu sürekli olarak ön plana çlkarılır ve

${ }^{3}$ Uluslararası hukuki metinlerde din eğitimi alanıyla ilgili yapılmış düzenlemeler hakkında ayrıntılı bilgi için bkz. Turan, 2012; Köprülü, 2019. 
öğrencilere -dolaylı şekilde dahi olsa- asıl benimsenmesi gereken yorumun bu olduğu mesajı verilirse, bu durum kültürlerarası din eğitimi yaklaşımıyla bağdaşmayacaktır. Farklı inançlara ya da yorum biçimlerine belirli bir inancın veya yorumun üstünlügünü fark ettirmek ve ona olan bağlllığın daha da kuvvetlenmesini sağlamak maksadıyla yer verilmesi durumu için de aynı şeyi söylemek mümkündür.

Dini ya da din anlayışı farklı olan bireyler aynı toplum içerisinde birlikte yaşayacaklar ise bu insanların birbirlerini çeșitli yönleriyle tanımaları elzemdir. Bu her șeyden önce insana saygı ilkesinin bir gereğidir. Sosyal çevresindeki bireyler tarafından yok sayılmak bir insana verilebilecek en büyük ceza ve hakarettir. Toplumun bir parçasını teşkil ettiği halde diğerleri tarafından tanınma ihtiyacı duyulmayan bireylerin bu durumdan dolayı hissedecekleri duygular hemen herkes tarafından tahmin edebilir. Bu duyguların toplumsal barışa ve huzura olumsuz yansıyacağında da kuşku bulunmamaktadır. Hal böyle iken din dersi için öğretim programları hazırlanırken din ya da din anlayışındaki farklılıkların görmezden gelinmesi, dinin farklı yorumlarını benimsemiş kişilere karşı dışlayışı/ötekileştirici bir dil kullanılması isabetli bir yaklaşım olmayacaktır. Bununla birlikte söz konusu farklılıkları öğretime konu etmenin birtakım risklerinin bulunduğu gerçeği de mutlaka göz önünde bulundurulmalıdır. Zira bu iş öylesine hassastır ki, önemsiz görülen bir yanlış, toplumdaki fay hatlarının daha da derinleșmesi sonucunu doğurabilir. Meselenin hassasiyeti, dinin birey ve toplum üzerindeki etkisinin büyüklüğünden, toplumumuzun dini yapısından ve tarihsel süreçte yaşanan acı tecrübelerden kaynaklanmaktadır.

Ülkemizde dini ya da din anlayışı farklı olan bireyler öteden beri bir arada yaşamaktadırlar. Birbirleriyle kucaklaşmaları, barış ve huzur içerisinde yaşamaları için gerekli ortak noktalar yeterince bulunsa da onlar çeşitli faktörlerin etkisiyle birbirlerine kuşku ile yaklaşabilmekte ve birbirleriyle sağlıklı ilişkiler kurma noktasında güçlükler yaşayabilmektedirler. Onların birbirlerine yönelik önyargılara sahip oldukları ve bu önyargıların yıkılmasının da birbirleri hakkında objektif bilgiye yeterince sahip olmalarına bağlı olduğu da bir gerçektir. Bütün bunlar esasen kültürlerarası din eğitiminden yararlanmanın ülkemiz açısından arz ettiği ehemmiyeti göstermektedir. Zira dinî ve toplumsal gerçekliklerimize uygun şekilde yapılandırılacak kültürlerarası din eğitimi hizmetleri, bireylerin farklı olanı doğru şekilde anlamlandırıp ona yönelik sağlıklı tepkiler geliștirmelerine ve kendilerini farklı kılan özellikleri fark edip onları koruyabilmelerine büyük katkılar sunabilir.

Din eğitimi sürecinde bireylerin aile ortamında öğrendikleri dini bilgilere ve edindikleri tecrübelere gereken değerin verilmemesi pedagojik açıdan onaylanabilecek bir davranış değildir. Zira modern eğitim anlayışının belkemiğini 'öğrenci merkezlilik' teşkil etmektedir. Bu anlayışa bağlı olarak eğitim sürecinde öğrenciler arasındaki bireysel farklılıkların dikkate alınması, öğretime konu edilen içeriğin öğrencilerin hayatıyla, ihtiyaçlarıyla ve sorunlarıyla ilişkilendirilmesi gerektiği belirtilmektedir. ${ }^{4}$ Kültürlerarası din eğitimi, işte bu anlayışın din eğitimi alanına da yansıtılması gerektiği düşüncesini temel almaktadır.

Günümüzde bireylerin, hayatlarının henüz ilk yıllarından itibaren kültürel açıdan farklı olan kişilerle etkileşim kurmaya başladıkları bir gerçektir. Bu durum gelişimin birçok alanında olduğu gibi dini ve ahlaki gelişim açısından da birtakım güçlükleri beraberinde getirmektedir (Bayrakdar, Denizer, Avcı ve Saygıll, 2017). Din eğitiminde geleneksel yaklaşımları ve uygulamaları aynen devam ettirerek çağımızın meydan okumaları karşısında dik duruşunu muhafaza edip küresel toplumun etkin bir üyesi olacak bireyleri yetiştirmek artık mümkün değildir (Aydın, 2009). Zira toplumun önemli bir kesiminin tecrübesiyle sabittir ki, korku ve baskının hâkim olduğu ortamlarda ezberci ve nakilci anlayış esas alınarak ve çoğunlukla düz anlatım yöntemi kullanılarak bireylere belirli bir dini ya da din anlayışını benimsetmeye çalışmak pek de olumlu neticeler vermemektedir (Aydın, 2008).

Din eğitimi alanında bir anlayış değişimine gidilmesinin gerekliliğinin devletin ilgili kurumları tarafından fark edilmesi ancak 2000'li yıllarda olmuștur. Zira din dersi için yürütülen program geliştirme çalışmalarında geleneksel ilmihal merkezli yaklaşım ${ }^{5} 2000$ 'li yıllardan itibaren terk edilmeye başlanmış; 'dini öğrenme' modeli, yerini büyük ölçüde 'dinden öğrenme' modeline bırakmıştır (Ev, 2010). Program geliştirme sürecinde öğrencinin gelişim dönemi özelliklerinin, ilgilerinin, ihtiyaçlarının ve sorunlarının merkeze alınması; bilişsel, dini ve ahlaki gelişiminin sağlıklı

\footnotetext{
${ }^{4}$ Din eğitimi sürecinin öğrenciyi merkeze alarak yapılandırılmasının önemi konusunda ayrıntılı bilgi için bkz. Aydın, 2011 b. $5 \mathrm{Bu}$ yaklaşımda, İslam dininin fıkıh disiplinin bakış açısıyla sunulması esas olup İslam içi yorum farklılıklarına ve İslam'ı bireysel ve toplumsal hayat üzerindeki güncel yansımalarına yer verilmez.
} 
şekilde gerçekleşmesine öncelik verilmesi için de 2000'li yılların gelmesi gerekmiştir. Öğrencinin bilgi karşısında edilgen değil, etkin konumda görülmesi 2000'li yıllarda geliştirilen programları öncekilerden ayıran bir başka özellik olmuştur. Yine 2000'li yıllardan itibaren İslam dışındaki dinlere ve İslam içi farklı oluşumlara program içerisinde daha fazla yer verilmeye başlanmış ve hatta bunlar nesnel yaklaşımla ele alınmaya çalışılmıştır (Zengin, 2017; Yörük, 2016).

2000'li yıllarda zorunlu din dersi için hazırlanan öğretim programlarında bilimsel ve çoğulcu yaklaşımların izleri önceki programlara nazaran daha fazla görülse de halkımızın bir kesimi, çocuklarının bu dersi almalarına yine de razı olmamıştır. Bu kişilerden bir kısmı haklarını yasal yollardan aramaya yönelmiş ve hatta gerek ulusal gerekse uluslararası mahkemelerde istedikleri sonuçları alabilmişlerdir. ${ }^{6} \mathrm{Bu}$ kapsamdaki davaların sonuçlarına bakıldığında mahkemeler tarafından hak ihlali olarak yorumlanan durumun, zorunlu din dersi uygulaması değil; zorunlu din dersleri için hazırlanan programların çoğulcu yaklaşımı yansıtmaması ve ülkemizdeki dinsel çeşitliğe yeterince yer vermemesi olduğu görülmektedir (Erken, 2020). Devletimizin bu noktada çözüm yolu olarak zorunlu din dersi uygulamasına son vermeyi değil, bu derse yönelik itirazları dikkate alarak öğretim programında kısmi düzenlemeler yapmayı tercih etmesi de kanaatimizce bundan kaynaklanmaktadır.

Milli Eğitim Bakanlığı 2013 yılında yaptığı bir düzenleme ile ortaokul ve lise müfredatına din alanıyla ilgili bir grup seçmeli ders eklemiştir. Bu düzenleme, toplumun belirli kesimlerinde, zorunlu din dersi programlarında çoğulcu ve nesnel yaklaşım temelinde birtakım düzenlemeler yapılacağına dair bir beklenti oluşturmuştur. 2018'de yapılan söz konusu düzenlemenin bu beklentiyi karşılayacak nitelikte olup olmadığı ise bilimsel araştırmalara henüz konu edilmemiştir.

Bu çalışmanın amacı, ilköğretim din kültürü ve ahlak bilgisi (IDKAB) dersi için geliştirilen son öğretim programının kültürlerarası din eğitimi açısından değerlendirilmesidir. Çalışmanın temel problemini, “IDKAB Dersi Öğretim Programı'nın kültürlerarası din eğitimi yaklaşımı ile uyumluluk durumu nedir?" sorusu teşkil etmektedir.

Çalışmada veriler nitel araştırma yöntemlerinden biri olan doküman incelemesi ile toplanmıștır. Doküman incelemesi, araştırılması hedeflenen olgu ya da olgulara dair bilgi içeren yazılı materyallerin analiz edilmesidir (Yıldırım ve Şimşek, 2008). Bu çalışma kapsamında analizi yapılan yazılı materyali ise 2018'de uygulanmaya başlanan IDKAB Dersi Öğretim Programı oluşturmaktadır. Araştırma sürecinde öncelikle literatür taraması yapılarak kültürlerarası eğitimle ilgili kavramlar açılığa kavuşturulmuştur. İDKAB Dersi Öğretim Programı bu kavramlardan yararlanılarak analiz edilmiştir.

Bu araştırmada, kültürlerarası din eğitimi, zorunlu din dersleri için yapılacak program geliştirme çalışmalarında model alınması değil, yararlanılması gereken yaklaşımlardan biri olarak ele alınmıştır. Kültürlerarası din eğitiminin hangi koşullarda, hangi amaçla ortaya çıktı̆̆ı bilinmeden; geçmişte yaşanan hadiselerden, toplumumuzun yapısından, dinden ve küresel gelişmelerden kaynaklanan hassasiyetler hesaba katılmadan model alınmasının doğru olmayacağı gerçeği araştırmanın hiçbir aşamasında göz ardı edilmemiştir.

\section{IDKAB Dersi Öğretim Programı'nın Kültürlerarası Din Eğitimi Açısından Değerlendirilmesi}

İDKAB Dersi Öğretim Programı üniteler, konular, kazanımlar, açıklamalar ve anahtar kavramlar şeklinde yapılandırılmıştır. Program üç bölümden oluşmuştur. Birinci bölümde, ilköğretim düzeyinde okutulan dersler için hazırlanmış ve halen yürürlükte olan öğretim programlarının dayandığı felsefi zemine dair açıklayıcı bilgilere yer verilmiştir. İkinci bölümde programın genel amaçları ve vizyonu belirtilmiştir. Üçüncü bölüm ise sınıf düzeylerine göre işlenecek ünitelere, bu ünitelere dair kazanımlara ve bunlara dair açıklamalara ayrılmıştır.

Halen yürürlükte olan İDKAB Dersi Öğretim Programı'nın, öncekine (2010 programı) göre oldukça sade olduğu dikkat çekmektedir. Önceki program 239 sayfadan müteşekkil iken mevcut program 40 sayfadan oluşmaktadır. Yeni programın daha sade şekilde hazırlanmış olması, DKAB öğretmenleri

\footnotetext{
$6 \mathrm{Bu}$ kapsamda açılan davalar hakkında AïHM tarafından verilen kararlar ve bunların gerekçeleri için bkz. Zengin, 2011b; Erken, 2020.
} 
tarafından daha kolay şekilde incelenmesine ve uygulanma sürecinde DKAB öğretmenlerine daha fazla inisiyatif kullanma imkanı verilmesi açısından önemlidir.

Önceki programda (2010) yer alan bazı hususlara yeni programda yer verilmediği dikkat çekmektedir. Örneğin önceki programda yer alan "İlköğretim Din Kültürü ve Ahlak Bilgisi Dersi Kazanımları ile İlişskilendirilen Ara Disiplinler" konusuna yeni programda gerek görülmemiștir. Önceki programda bulunup da yeni programda yer almayan bir diğer konu, ünitelerle ilgili etkinlik örnekleri olmuştur. Önceki program, konu başlıkları altında yer verilen bilgilerin daha ayrıntılı olması yönüyle de mevcut programdan ayrılmaktadır. Örnek vermek gerekirse önceki programda, ilgili olduğu alana (bireysel, toplumsal, kültürel, evrensel ve ahlaki) göre sınıflandırılmış toplam 28 genel amaç ifadesi yer alırken yeni programda sınıflandırma yapılmaksızın sadece 10 genel amaç ifadesine yer verilmiștir. Bunlar, yeni programda din dersi öğretmenlerinden daha fazla inisiyatif kullanmalarının beklendiği düşüncesini destekler niteliktedir.

Yukarıda belirtilen farklılıklarla birlikte iki program (2010 ile 2018 programları) arasında ortak noktalar da mevcuttur. Örneğin her iki programda da İslam dini hakkında Kur'an ve sünnet merkezli bilgilerin; İslam düşüncesinde ortaya çıkan yorumlar ile diğer dinler hakkında ise bilimsel araştırmalara dayalı bilgilerin esas alındığı belirtilmiştir. Esas alınan eğitsel yaklaşım temellendirilirken her iki programda da yapılandırmacılık, çoklu zekâ kuramı, öğrenci merkezli öğrenme gibi kavramlar kullanılmıştır. Ancak yeni programda yapılandırmacı yaklaşıma yapılan vurgu, önceki programa göre zayıf kalmıştır. Din dersi için yapılacak program geliştirme çalışmalarında yapılandırmacı yaklaşımın esas alınmasının imkânına ya da güçlüklerine dair akademik platformlarda paylaşılan görüşlerin, ${ }^{7}$ tercihin bu yönde kullanılmasında önemli etkenlerden biri olabileceği değerlendirilmektedir.

Öğretim programları dört temel öğeden oluşmaktadır. Bunlar; hedefler, içerik, öğrenme-öğretme süreci ve değerlendirmedir (Demirel, 2010). Ne var ki İDKAB dersi öğretim programında kültürlerarası din eğitimi açısından değerlendirilmesi gereken öğeler bunlardan ibaret değildir. Programın vizyonunu, temel felsefesini, programa esas teşkil eden temel değerler ve yetkinlikler ile ders kitapları hazırlanırken dikkat edilmesi gereken hususları yansıtan açıklamalar da kültürlerarası din eğitimi açısından dikkat çekici bulunmuștur. Bütün bu unsurlar programda üç bölümde ele alınmıştır. Bu nedenle İDKAB dersi öğretim programının kültürlerarası din eğitimi açısından değerlendirmesi, bölüm sayısı dikkate alınarak üç başlık altında yapılmıştır.

\section{IDKAB Öğretim Programı'nın Birinci Bölümünün Kültürlerarası Din Eğitimi Açısından Değerlendirilmesi}

Bu bölümde, öğretim programlarının geliştirilmesi sürecinde esas alınan yaklaşıma dair açıklayıcı bilgilere yer verilmiştir. Bu çerçevede "Öğretim Programlarının Amaçları", "Öğretim Programlarının Perspektifi", "Öğretim Programlarında Ölçme Değerlendirme Yaklaşımı", "Bireysel Gelişim ve Öğretim Programları" başlıklarına yer verilmiştir. "Öğretim Programının Perspektifi" başlı̆̆ı altında, öğrencilere kazandırılması hedeflenen temel değerler ve yetkinlikler belirtilmiştir. Bu bölüm, öğretim programını güncelleme sürecinde yapılan işlemlerin aşamalı şekilde belirtilip açıklandığı sonuç kısmıyla bitirilmiştir.

İDKAB Dersi Öğretim Programı'nın birinci bölümünde kültürlerarası din eğitimi açısından dikkat çekici bulunan ilk husus, ders konularının adalet, dostluk, dürüstlük, öz denetim, sabır, saygı, sevgi, sorumluluk, yardımseverlik gibi kök değerlerle ilişkilendirilmesinin önemine dikkat çekilmesi olmuştur (IDKAB Dersi Öğretim Programı, s. 3). Bu durum, kültürlerarası din eğitimi açısından olumludur. Zira evrensel değerleri özümsemiş bireyler yetiştirmek, kültürlerarası eğitimin bașta gelen amaçlarından birini teşkil etmektedir (Nayir ve Sarıdaş, 2020).

Türkiye Yeterlilikler Çerçevesi (TYÇ) kapsamında belirlenmiş olan ve öğretim programının başında yer verilen sekiz alanla ilgili yetkinlikler de kültürlerarası din eğitimi açısından dikkat çekici bulunmuştur. Zira bu sekiz alandan biri olan "sosyal ve vatandaşlıkla ilgili yetkinlikler" öğretim programında şu şekilde açılanmıștır: "Bu yetkinlikler kişisel, kişilerarası ve kültürlerarası yetkinlikleri içermekte; bireylerin farklılaşan toplum ve çalışma hayatına etkili ve yapıcı biçimde katılmalarına imkân tanıyacak; gerektiğinde çatışmaları çözecek özelliklerle donatılmasını sağlayan

${ }^{7}$ Bu görüşler için bkz. Kaymakcan, 2007; Zengin 2011a. 
tüm davranış biçimlerini kapsar." (IDKAB Dersi Öğretim Programı, s. 4). Bu ifadelerin kültürlerarası din eğitiminin hedefleriyle örtüştüğü rahatllkla söylenebilir.

Birinci bölümde, program geliştirme sürecinde bireysel farklllıklara ilişkin hassasiyetlerin göz önünde bulundurulduğunun belirtilmiş olması (IDKAB Dersi Öğretim Programı, s. 6) da kültürlerarası din eğitimi açısından önemlidir. Çünkü programda, çevresel ve kültürel farklılıkların da bireysel farklılıklar kapsamında ele alınması gerektiği belirtilmiștir (IDKAB Dersi Öğretim Programı, s. 6). Böylelikle din dersi öğretmenlerine -örtük şekilde de olsa- dini ya da din anlayışı farklı öğrencilerin hassasiyetlerini gözetmeleri gerektiği mesajı verilmiştir.

\section{IDKAB Dersi Öğretim Programı'nın İkinci Bölümünün Kültürlerarası Din Eğitimi Açısından Değerlendirilmesi}

İDKAB Dersi Öğretim Programı́nın ikinci bölümünde öncelikle programın temel felsefesi ve genel amaçları ortaya konulmuştur. Daha sonra ise programın vizyonu belirtilmiştir. Bu bölüm, ders kitabı yazımı sürecinde riayet edilmesi gereken ilkelere ve bunların açılamalarına yer verilerek bitirilmiştir.

İkinci bölümde "Programın Temel Felsefesi ve Genel Amaçları" başlı̆̆ı altında yer verilen şu ifadeler kültürlerarası din eğitimi açısından son derece önemlidir:

"Din Kültürü ve Ahlak Bilgisi Dersi (4-8. Sinıflar) Öğretim Programı İslam dini ve diğer dinleri betimleyici yaklașımla öğretime konu etmeyi amaçlamıștır. İslam dini, Kur'an ve sünnetin ortaya koyduğu temel ilkeler çerçevesinde esas alınmıştır. İslam düşüncesinde ortaya çılkan yorumlar bilimsel bir metotla ve mezhepler üstü bir yaklaşımla ele alınmıştır. Yaşayan diğer dinler ise bilimsel bir metotla, dinler açılımlı ve olgusal bir yaklaşımla öğretime konu edilmiştir." (IDKAB Dersi Öğretim Programı, s. 8)

İslam dininin tanıtımında Kur'an ve sünnette yer alan açı hükümlerin ve Müslümanların genelinin kabul etmekte zorlanmayacağı ilke ve değerlerin esas alınması ve bu yapılırken de İslam düşüncesinde ortaya çıkan yorum farklılıklarının görmezden gelinmediğinin belirtilmiş olması kültürlerarası din eğitimi açısından önemlidir. Çünkü ülkemizdeki Müslümanlar tek bir mezhebe bağlı değildir. İslam düşüncesinde ortaya çıkan farklı yorumları benimsemiş bireyler aynı toplumda birlikte yaşamaktadırlar. Bu durum aynı sınıfta öğrenim gören öğrenciler için de geçerlidir. İslam düşüncesinde ortaya çıkan yorum farklılıklarının programda görmezden gelinmemiş olması, mensup oldukları dini gruptan dolayı öğrencilerin kendilerini dışlanmış hissetmemeleri açısından ehemmiyet arz etmektedir. İslam düşüncesindeki yorum farklılıklarının ele alınmasında bilimsel yaklaşımın esas alınmış olması da kültürlerarası din eğitimi açısından olumlu bir durumdur. Ancak kanaatimiz odur ki, programın mezhepler üstü yaklaşımla hazırlanmış olması, bu iddiaların en azından bir kısmının sözde kalması sonucunu doğurabilir. Zira söz konusu iddialar mezhepler üstü yaklaşımın yanı sıra mezhepler arası yaklaşımdan da yararlanılmasını gerektirmektedir. Mezhepler üstü yaklaşımda ortak noktalardan hareket edilmesi ve yorum farklllıklarının mümkün olduğunca gündeme getirilmemesi esastır. Mezhepler arası yaklaşımda ise farklılıklara yönelik daha olumlu bir bakış söz konusudur. Zira bu yaklaşım, farklılıkların bir zenginlik olarak görülmesi ve din eğitimi sürecinde birlikte öğretime konu edilmesi esasına dayanmaktadır. ${ }^{8}$

Çıkış noktası olarak din içi yorum farklılıklarının alındığı bir DKAB dersi, ilköğretim kademesi için elbette uygun olmayacaktır. Çünkü mensubu bulundukları dinin temel esasları hakkında dahi yeterli birikime sahip olmayan öğrencilere din içerisindeki yorum farklılıklarını öğretmeye çalışmak onların dine yönelik tutumlarını olumsuz etkileyebilir. Bununla birlikte din derslerinde ortak noktalar öğretime konu edilirken mezhepler arasındaki farklı görüş ve uygulamalara -ortak noktaları aşındırmayacak şekilde- yer verilmesi de gerekebilir. Böyle bir yaklaşım öğrencilerin hem farklı olanı doğru şekilde anlamlandırıp ona doğru tepkiler verme hem de kendi dindarlıklarını sağlıklı şekilde oluşturma ihtimallerini arttıracaktır (Aydın, 2019).

"Programın Temel Felsefesi ve Genel Amaçları" başlı̆̆ altında İslam dışındaki dinlerin bilimsel bir metotla, dinler açılımlı ve olgusal bir yaklaşımla öğretime konu edileceğinin belirtilmiş olması kültürlerarası din eğitimi açısından olumludur. Ancak programda, İslam dışındaki dinlerin

${ }^{8}$ Din öğretiminde mezhepler üstü ile mezheplerarası yaklaşımlar hakkında geniş bilgi için bkz. Tosun, 2010. 
öğretimine ayrılmıș bir ünitenin bulunmadığı görülmüștür. ${ }^{9}$ Ders konularının İslam dışındaki dinlerin yaklaşımları ile birlikte işlenmesi gerektiğine dair bir hatırlatmaya da programda yer verilmemiştir. Bu durum programı oluşturan öğeler arasında olması gereken bütünlüğün/tutarlılığın yeterince sağlanamadığını göstermektedir.

İkinci bölümde, kültürlerarası din eğitimi açısından oldukça önemli olan bir diğer kısım programın genel amaçlarıdır. Bu amaçlar arasında kültürlerarası din eğitimini doğrudan ilgilendirenler şunlardır:

(2) Dinin sosyal hayat, kültür ve medeniyet unsurları üzerindeki etkilerini kavramaları,

(3) Farklı inanç ve yorumları tanımaları ve bunlara saygı duymaları,

(4) Çevresindeki dinî davranış, yorum, tutum ve deneyimlerin farkında olmaları. (IDKAB Dersi Öğretim Programı, s. 8).

$\mathrm{Bu}$ ifadelerden her birinin kültürlerarası din eğitiminin ilkeleri ile uyumluluk arz ettiği rahatlıkla söylenebilir. Ne var ki ünitelerde yer verilecek konuların seçimi ve bu konulara dair içeriğin oluşturulması sürecinde bu amaçların yeterince dikkate alındığını söylemek oldukça güçtür.

İkinci bölümde kültürlerarası din eğitimi açısından ehemmiyet arz eden bir diğer kısım, programın vizyonudur. Programın vizyonu şu şekilde ifade edilmiştir:

Dinin hayatı anlamlandırmadaki rolünü fark eden; millî, manevi ve ahlaki değerleri benimseyen; farklllıklarla bir arada yaşama becerisi kazanmış bireyler yetiştirmektir (IDKAB Dersi Öğretim Programı, s. 9).

Bu ifade, kültürlerarası din eğitimi açısından gayet olumludur. Çünkü bireylere, farklılıklarla bir arada yaşama becerisinin kazandırılması, kültürlerarası din eğitiminin başta gelen amaçlarından biridir.

Bu bölümde "Programın Uygulanmasına/Kitap Yazımına İlişkin İlke ve Açıklamalar" başlığı altında yer verilen aşağıdaki ifadeler de kültürlerarası din eğitimi açısından dikkat çekicidir:

(4) Gerek farklı din ve inançların öğretiminde gerekse İslam düşüncesinde ortaya çıkan yorumların öğretiminde olgusal bir yaklaşım benimsenir; bu bağlamda dinler, inançlar ve İslam düşüncesinde yer alan yorumlar, kendi metinleri, kaynakları ve kabulleri esas alınarak öğretime konu edilir.

(5) İslam dininde yer alan ibadetlerin öğretiminde (abdest, gusül, teyemmüm, namaz, vb.) mezheplerin farklı anlayış ve uygulamalarıyla ilgili bilgiler ihtiyaç duyulması hâlinde öğretmenler tarafindan açıklanır.

(8) Öğrenciler; konularda geçen ayet ve hadisler ile ünite sonlarında yer alan sure ve duaları ezberlemeye zorlanmaz.

(9) Din, vicdan ve düşünce özgürlüğünü zedeleyici yaklaşım, tutum ve davranışlardan uzak durulur. Bu bağlamda öğrenciler dinî duygu ve düşüncelerini açılklamaya, bilgi ve kültür sahibi oldukları dinî pratikleri yerine getirmeye zorlanmaz (IDKAB Dersi Öğretim Programı, s. 9)

Yukarıdaki ifadeler arasında kültürlerarası din eğitimi açısından olumsuz bir durum bulunmamaktadır. Hatta bu ifadelerin kültürlerarası din eğitiminin ilkeleriyle tamamen örtüştüğü de söylenebilir. Ancak bu ifadelerin ünitelere ne ölçüde yansıdığı tartışmaya açık bir meseledir. Dördüncü maddedeki ifadeler, üniteler içerisinde yer verilen konuların farklı dinlerin bakış açıları ve İslam düşüncesinde ortaya çıkan yorumlar eşliğinde ele alınmasını gerektirmektedir. Ne var ki ünitelerle ilgili açılamalar içeren üçüncü bölüm incelendiğinde böyle bir durumun söz konusu olmadığı kolaylıkla fark edilebilmektedir. Zira programda, İslam dışındaki dinlerin tanıtıldığı bir ünite bulunmadığı; İslam düşüncesinde ortaya çıkan yorumları tanıtıcı nitelikteki bilgilerin ise ünitelere dağıtılmadığı, tek ünitede toplanmış olduğu görülmektedir.

Programı oluşturan öğelerin birbiriyle uyumluluğu/tutarlılığı basit bir mesele değildir. Söz konusu olan DKAB gibi hassasiyet derecesi oldukça yüksek bir ders ise bu meselenin önemi daha da

${ }^{9}$ DKAB dersi için belirlenen haftalık ders saati sayısı dikkate alındığında programda farklı dinlere yer verilmesinin ya da konuların farklı dinlerin yaklașımları gündeme getirilerek ișlenmesinin imkânı elbette tartıșlabilir. Ancak bu, üstesinden gelinemeyecek bir güçlük değildir. DKAB’ın haftalık ders saati sayısı arttırılarak bu güçlüğün üstesinden gelinebilir. 
artmaktadır. Programın öğeleri arasındaki uyumluluğun, onu uygulayacak öğretmenlerin ders sürecinde yaşadıkları kaygıların giderilmesine, derste ilkeli ve kararlı davranmalarına yapacağı katkı yadsınamaz. Bunların, dersin verimliliği ile ilişsisinin ne kadar güçlü olduğu ise izahtan varestedir.

\section{IDKAB Dersi Öğretim Programı'nın Üçüncü Bölümünün Kültürlerarası Din Eğitimi Açısından Değerlendirilmesi}

İDKAB Dersi Öğretim Programı́nın üçüncü bölümüne, programın genel yapısı hakkında bilgi verilerek başlanmıştır. Sınıf düzeylerine göre işlenecek üniteler, ünitelerde hedeflenen kazanım sayıları, ünitelerin işlenişi için öngörülen ders saati sayıları ve bu sayıların toplam ders saati içerisindeki oranı tablolar halinde gösterilmiştir. Bu bölümde son olarak sınıf düzeylerine göre işlenecek üniteler ve ünitelerin kazanımları belirtilmiş; ünitelerin işlenişinde dikkat edilmesi gereken hususlara dair uyarı mahiyetinde açıklamalara yer verilmiştir.

Bir makale çalışması kapsamında, İDKAB Dersi Öğretim Programı'nda yer verilen ünitelerden her birinin kültürlerarası din eğitimi açısından değerlendirmesini yapmanın isabetli bir tercih olmayacă̆ı açıktır. Bu nedenle üniteler arasından, değerlendirilmek üzere sadece kültürlerarası din eğitimi ile doğrudan ilişkili bulunanlar seçilmiştir. Seçilen ünitelere dair değerlendirmeler aşağıda ortaya konulmuştur.

\section{Sınıf 1. Ünite: Günlük Hayattaki Dini İfadeler}

Sadece başlığına bakıldığında dahi bu ünitenin kültürlerarası din eğitimi açısından arz ettiği önemin büyüklüğ̈ kolaylıkla fark edilebilmektedir. Programda "Allah (c.c.), peygamber, eûzü besmele, selam, hamd, şükür, tekbir, salâvat, estağfirullah, sübhanallah, helal, haram, günah, sevap, Allah razı olsun, Allah'a emanet ol, Allah şifa versin, inşallah, maşallah" gibi Müslümanların günlük hayatta sıkça kullandıkları dini ifadelere anlamlarıyla birlikte yer verilmesi istenmiştir. Günlük hayatta kullanılan dini ifadeler kuşkusuz bunlarla sınırlı değildir. Ancak dördüncü sınıf düzeyindeki öğrencilere bir ünite kapsamında ancak bu kadar ifadenin tanıtılabileceği gerçeğinin de göz ardı edilmemesi gerekir. Ünite kapsamında öğretilmek üzere seçilen dini ifadelerin, mensubu bulunduğu dini grup ve hatta dindarlık düzeyi ne olursa olsun halkımızın geneli tarafından kullanılıyor olması kültürlerarası din eğitimi açısından olumlu bir durumdur. Bununla birlikte öğretim programında şöyle bir açılklamaya yer verilmesinin kültürlerarası din eğitimi açısından daha isabetli bir tercih olacağı değerlendirilmektedir: "Okulun içerisinde bulunduğu yerleşim biriminin dini yapısı da dikkate alınarak o bölgede yaygın șekilde kullanılan yöresel dini ifadeler varsa tespit edilebilir ve bu ifadelerin hangi anlamda ve ne amaçla kullanıldığı meselesine derste açıklık getirilebilir." Böyle bir açıklama ünitenin, programın vizyonu ve genel amaçları ile uyumlu şekilde işlenmesine katkı sağlayabilir. Zira dinin günlük dile yansımasının yöreden yöreye farklılaşabildiği gerçeğini fark etmeleri öğrencilerin anlam dünyalarının genişlik kazanmasına ve farklılıkları doğru şekilde anlamlandırmalarına vesile olabilir.

\section{SInıf 1. Ünite: Allah İnancı}

Bu üniteyi kültürlerarası din eğitimi açısından önemli kılan temel unsur, toplumumuzun genelinin üzerinde ittifak ettiği bir inanç esasına yer verilmiş olmasıdır. Zira din anlayışı ne olursa olsun toplumumuzun en az \%90'ı yüce Allah'ın varlığına inanmaktadır. ${ }^{10 U ̈ n i t e d e, ~ A l l a h ' ı ~ t a n ı t m a k ~}$ maksadıyla ön plana çıkarılan hususların mahiyeti de kültürlerarası din eğitimi açısından önem arz etmektedir. Zira Müslümanlar arasında ihtilaf kaynağı olan hususlara ünitede yer verilmediği dikkat çekmektedir. Bu ünite kapsamında kültürlerarası din eğitimi açısından dikkat çekici bulunan bir başka husus, altıncı kazanıma dair yapılan açıklamalar arasında yer verilen şu ifadedir: "Nehcü'lBelâğa"dan ve dilimize yerleșen kalıplaşmış dua cümlelerinden örnekler verilmeye özen gösterilir." (IDKAB Dersi Öğretim Programı, s. 21). Din dersi öğretmenlerinin Alevilik'te ve Şiilik'te çok önemli olan bir eserden yararlanmaya yöneltilmiş olmaları kültürlerarası din eğitimi açısından olumlu bir durumdur. Bununla birlikte programda, dua örneklerine yer verilecek söz konusu eser hakkında öğrencilere bilgi vermelerinin gerekip gerekmediği hususu açıklığa kavuşturulmamıștır. Bu, kanaatimizce önemli bir eksikliktir. Zira verilen dua örneklerinin değerine dair sağlıklı kanaatler geliştirmeleri için öğrencilere söz konusu esere dair tanıtıcı nitelikte bilgiler verilmesi gerekir.

10 DİB tarafından 2013'te yapılıp 2014'te yayınlanan araştırmaya göre halkımız içerisinde Allah'ın varlığına inananların oranı \%98.7'dir (DİB, 2014). 
İçerisinden dua örnekleri almaya değer bulunan bir eserin öğrencilere tanıtılmaması önemli bir eksikliktir.

\section{Sinıf 2. Ünite: Ramazan ve Oruç}

Ramazan ayı, dinin bireysel ve toplumsal hayat üzerindeki yansımalarının en bariz şekilde görüldüğü zaman dilimini olușturmaktadır. Ramazan ayında oluşan manevi atmosferden az ya da çok toplumun her kesimi etkilenmektedir. Bu nedenledir ki halkımız, Ramazan ayına özgü gelenekleri yaşatmaya büyük önem vermektedir. Bu gelenekler arasında kuşkusuz yöresel farklılıklar da bulunmaktadır. $\mathrm{Bu}$ farklılaşmada, İslam düşüncesindeki yorum farklılıklarının etkisi yadsınamaz. Bu bakımdan "Ramazan ve Oruç", kültürlerarası din eğitimi açısından son derece önemli bir ünitedir.

Öğretim programında bu ünitenin kazanımlarından birinin, "Kültürümüzde Ramazan ve oruçla ilgili gelenekleri tanır" (IDKAB Dersi Öğretim Programı, s. 22) olduğu belirtilmiştir. Derste tanıtılacak Ramazan gelenekleri arasında ön plana çıkarılanlar ise mukabele okuma, mahya, hırka-i şerif ziyareti, diş kirası, tekne orucu olmuştur. Bunlar, hangi dini gruba mensup olursa olsun her Müslümanın hayatında yeri olan geleneklerdir. Bu bakımdan söz konusu kazanımın, kültürlerarası din eğitimi açısından gayet olumlu olduğu söylenebilir. Öğrencilerin Ramazan ayına özel gelenekleri tanımalarının, bunları sahiplenerek kendi kültürlerini yașatmaları açısından önemli olduğunu da bu noktada belirtmekte fayda vardır.

\section{SInıf 4. Ünite: Hz. Muhammed Ve Aile Hayatı}

Müslümanların geneli tarafından peygamberliği kabul edilen, sevilen ve hürmet gösterilen bir şahsiyeti konu edinmesi bu üniteyi kültürlerarası din eğitimi açısından önemli kılan temel unsurdur. Ünitede Hz. Muhammed'in (sas) aile içerisindeki örnek davranışlarının ön plana çıkarıldığı ve Müslümanlar içerisinde herhangi bir kesimin itirazına konu olabilecek hususlara yer verilmediği dikkat çekmektedir. Bunlar, kültürlerarası din eğitimi açısından gayet olumludur. Bu ünitenin kazanımlarından birinin "Hz. Hasan (r.a.) ve Hz. Hüseyin'in (r.a.) ahlaki erdemlerini kendisine örnek alır" olması da kültürlerarası din eğitimi açısından dikkate değer bir durumdur. Çünkü Hz. Hasan ve Hz. Hüseyin İslam içi farklı oluşumların hepsi tarafından değer verilen şahsiyetlerdir.

\section{Sınıf 5. Ünite: Çevremizde Dinin İzleri}

Kültürlerarası din eğitimi açısından büyük ehemmiyet arz eden bu ünite ile ilgili olarak programda, "Örfve âdetlerimizde yer alan dinî unsurları fark eder" (IDKAB Dersi Öğretim Programı, s. 25) şeklinde bir kazanıma yer verilmiş ve bu kazanım dügün, sünnet, isim koyma, mevlit merasimleri, kandiller ve bayramlaşma ile sınırlı tutulmuştur (IDKAB Dersi Öğretim Programı, s. 25). Programda, konuların günlük hayattan ve öğrencilerin somut deneyimlerinden örneklerle işlenmesi gerektiği, diğer birçok ünitede olduğu gibi bu ünitede de vurgulanmıştır (IDKAB Dersi Öğretim Programı, s. 25). Bununla birlikte İslam dininin günlük hayat üzerindeki yansımalarının yöreden yöreye farklılık gösterdiği açık bir gerçek olmasına rağmen bu farklılıkların sınıf ortamına taşınıp taşınmayacağı; taşınacaksa bu süreçte nelere dikkat edilmesi gerektiği hususu netliğe kavuşturulmamıştır. Bu durum, kültürlerarası din eğitimi açısından bir eksiklik olarak değerlendirilebilir.

\section{Sinıf 2. Ünite: Namaz}

Öğretim programında bu ünitenin işlenişine dair, "Namazla ilgili konuların öğretiminde mezheplerin farklı anlayış ve uygulamaları ihtiyaç duyulması hâlinde öğretmenler tarafından açıklanır" (IDKAB Dersi Öğretim Programı, s. 27) şeklinde bir açıklamaya yer verilmiştir. İslam içi çoğulluğa verilen değeri göstermesi bakımından bu ifade önemlidir. Bununla birlikte söz konusu ifadenin din dersi öğretmenleri için yeterince açık olmadığını da belirtmek gerekir. Zira mezheplerin namazla ilgili farklı anlayış ve uygulamalarına açıklama getirmenin hangi durumlarda bir gereklilik olarak görüleceği meselesi açıklı̆̆a kavuşturulmamıştır. Ayrıca namazla ilgili farklı anlayış ve uygulamalara açıklık getirilirken nelere dikkat edilmesi gerektiği; söz konusu anlayış ve uygulamaların sihhatine dair açıklama yapılıp yapılmayacağı da belirsiz bırakılmıştır. Oysa bunlar, din dersi öğretmenlerinin inisiyatifine bırakılmayacak kadar hassas meselelerdir.

\section{Sınıf 3. Ünite: Zararlı Alışkanlıklar}

Bu ünitede içki içmek, sigara kullanmak, kumar oynamak, uyuşturucu madde kullanmak gibi zararlı alışkanlıklara yer verilmiş; bu alışkanlıkların yol açacağı olumsuzluklar ve bu alışkanlıklardan 
korunma yolları hususunda öğrencilere bilinç kazandırılması hedeflenmiștir. Söz konusu alışkanlıkların Müslümanların geneli tarafından zararlı olarak nitelendirildiği açıktır. Bu bakımdan bu ünite kapsamında yer verilen kazanımlardan her birinin, kültürlerarası din eğitimi açısından önem arz ettiği rahatlıkla söylenebilir.

Zararlı alışkanlıklar ünitesi, öğrencilerin konuya akılcı ve eleştirel yaklaşmaları için din dersi ögretmenlerine hatırlatma yapılan (IDKAB Dersi Öğretim Programı, s. 28) iki üniteden biridir. ${ }^{11}$ Oysa akılcı ve eleștirel yaklașım kültürlerarası din eğitiminin olmazsa olmazlarından biridir (Aydın ve Osmanoğlu, 2015). ${ }^{12}$ Bu yaklaşım göz ardı edildiği takdirde kültürlerarası din eğitimi ile hedeflenen kazanımların gerçekleşmesi mümkün değildir. Dinin, farklı din anlayışlarını benimsemiş gruplar arasında nefreti ve ayrımcılığı körükleyen bir unsura dönüştürülmesinin kaynağında akletme yetisinin doğru ve etkin şekilde kullanılmamasının rolü büyük olmasına rağmen akılcı ve eleștirel yaklaşımın programın geneline yansımamış olmasının kültürlerarası din eğitimi açısından onaylanması mümkün değildir. Dinin kardeşlik, birlik, dayanışma ve yardımlaşma duygularının gelişmesine katkı sağlayan bir unsur olarak işlev görmesi hedefleniyorsa, dini hassasiyetlerini istismar etmek isteyen kişi ya da gruplara yönelik öğrencilerin farkındalık düzeylerini arttırmaya yönelik eğitsel faaliyetlere ağırlık verilmesi yerinde olacaktır. Eğitim hizmetlerinin eleştirel/sorgulayıcı düşüncenin gelişmesine hizmet edecek şekilde yapılandırılması bu konuda mesafe alınması açısından oldukça önemlidir. Çünkü düşünme becerilerinin sağlıklı şekilde gelişmesi bireylerin güdümlü/bağımlı kişilik geliştirme ihtimallerini önemli ölçüde azaltacaktır. Eleştirel düşüncenin önemsenmediği din eğitimi hizmetleri ile açlk toplumun öz yönetimli dindarının yetiştirilmesinin mümkün olmadığını da bu noktada belirtmekte fayda vardır (Aydın, 2011a).

\section{Sinıf 4. Ünite: Hz. Muhammed'in Hayatı}

$\mathrm{Bu}$ ünitede kültürlerarası din eğitimi açısından dikkate değer bulunan husus, din dersi öğretmenlerinden bu üniteyi işlerken Hz. Muhammed'in (sas) Medine'de diğer din mensupları ile ilişkilerine yer vermelerinin istenmiş olmasıdır (IDKAB Dersi Öğretim Programı, s. 29). Ancak bu yapılırken Hz. Muhammed'in (sas) diğer din mensupları ile ilişkilerini hangi esaslar çerçevesinde yürüttüğüne dair bir açılklamaya yer verilmemiştir. Anlaşılan o ki bu meselenin çözümü, hazırlanacak ders kitaplarına ve din dersi öğretmenlerine bırakılmıştır. Burada kültürlerarası din eğitimi açısından asıl sorun, öğretim programında Hz. Muhammed'in (sas) diğer din mensupları ile ilişkilerine yer verilirken, İslam dışındaki dinler hakkında objektif bilgiler içeren bir üniteye yer verilmemiş olmasıdır. ${ }^{13} \mathrm{Bu}$ durum, Hz. Muhammed'in (sas) diğer din mensupları ile ilişkilerinin öğrenciler tarafından doğru şekilde anlamlandırılma ve örnek alınma ihtimalini düşürebilir. Söz konusu durumun, programın genel amaçları ile uyuş̧madığı da rahatlıkla söylenebilir. Zira programın genel amaçlarından birini, farklı dini inançları tanıma ve bunlara saygı duyma oluşturmaktadır (İDKAB Dersi Öğretim Programı, s. 8). Öğrencilerin, hakkında sağlıklı bilgiye sahip olmadıkları dini inançlara ve bunların mensuplarına saygı ile yaklaşmalarının nasıl mümkün olacağı, izahı güç bir meseledir.

\section{Sınıf 5. Ünite: Temel Değerlerimiz}

$\mathrm{Bu}$ ünitede toplumu oluşturan fertleri birbirine bağlayan, milli birlik ve beraberliğin korunup güçlendirilmesi açısından önemli olan vatan, millet, bayrak, şehitlik, gazilik, ehl-i beyt sevgisi gibi değerlere yer verilmiştir (IDKAB Dersi Öğretim Programı, s. 30). Toplumun ortak değerlerinin ön plana çıkarılmış olması, kültürlerarası din eğitimi açısından önemlidir. Zira kültürlerarası din eğitiminin başta gelen hedeflerinden birini toplumu oluşturan fertlerin bir arada barış ve huzur içerisinde yaşamalarının temini oluşturmaktadır.

\section{Sinıf 2. Ünite: Hac ve Kurban}

Öğretim programında bu üniteyle ilgili kültürlerarası din eğitimi açısından ehemmiyet arz eden husus, din dersi öğretmenlerinden Alevi Bektaşi geleneğindeki “Kurban Tığlama Duası”na yer

\footnotetext{
11 Programda eleştirel yaklaşımla ele alınması istenen bir başka konu 8. Sınıf Kader ünitesinde yer verilmesi istenen kader ve kaza ile ilgili yanlış kanaatlerdir.

${ }^{12}$ Ayrıca din eğitimi sürecinin eleştirel düşüncenin gelişmesine katkı sağlayacak şekilde yapılandırılmasının gerekliliğine dair görüşler için bkz. Kılıç, 2019.

${ }^{13}$ Bir önceki ögretim programında İslam dıșındaki dinlerin tanıtılması için “Dinler ve Evrensel Öğütleri” başlıklı bir üniteye yer verilmiş olsa da yeni programda böyle bir ünite gerekli görülmemiştir.
} 
vermelerinin" (IDKAB Dersi Öğretim Programı, s. 32) istenmiş olmasıdır. Ancak Alevi Bektaşi geleneğinde kurban ibadetine yönelik yaklaşımın ne olduğu, hangi zamanlarda hangi maksatlarla kurban kesildiği meselesine açılılı getirilmeden sadece "Kurban Tığlama Duası"na yer verilmekle konunun geçiştirilmesinin kültürlerarası din eğitimi açısından sorunlu bir yaklaşım olduğunu da belirtmek gerekir. Çünkü öğrencilerin büyük çoğunluğu kuvvetle muhtemeldir ki bu duayı ilk defa duymuş olacaklardır. Kaynağının ne olduğu, hangi yörede kimler tarafından gelenek haline getirildiği ve ehemmiyetinin nereden kaynaklandığı ortaya konulmadan söz konusu duanın derste öğrencilerle paylaşılmasııın dersin kazanımları açısından bir anlam taşımayacağı açıktır.

\section{Sınıf 5. Ünite: İslam Düşüncesinde Yorumlar}

IDKAB Dersi Öğretim Programı'nda kültürlerarası din eğitimi açısından en dikkat çekici ünitedir. Bu ünitede sırasıyla; din anlayışındaki yorum farklılıklarının sebepleri, İslam düşüncesinde yorum biçimleri, İslam düşüncesinde tasavvufi yorumlar konularına yer verilmiştir. İslam düşüncesindeki yorum farklılıkları öğrencilerle paylaşılırken nesnel ve tasviri (betimleyici) anlatımın esas alınması gerektiği belirtilmiştir (IDKAB Dersi Öğretim Programı, s. 35). Din dersi öğretmenlerinden farklı yorum biçimlerini öğretime konu ederken tarafsız bir yaklaşım sergilemeleri istenmektedir. Bu durum kültürlerarası din eğitimi açısından olumludur. Bununla birlikte söz konusu tarafsızlığın sözde kalmaması için ders sürecinde nelere dikkat edilmesi gerektiği hususuna açılılı getirilmemiş olması ciddi bir sorundur. Zira din dersi öğretmenleri sınıfta -farkında olarak ya da olmadan- doğru olduğuna inandıkları yorumlar lehine tavır sergileyebilir, öğrencileri açık ya da örtük şekilde belirli yorumları benimsemeye yönlendirebilirler. Kültürlerarası din eğitimi açısından sakıncalı görülen bu tür durumlara meydan verilmemesi için gerekli kllavuz ilkelerin belirlenmesi ve bunlara öğretim programında yer verilmesi yerinde olacaktır.

Bu ünitede İslam düşüncesindeki yorum biçimleri inançla ilgili yorumlar, fikhi yorumlar ve tasavvufi yorumlar şeklinde üç grupta ele alınmıştır. Ünite içerisinde tasavvufi yorumlara ve özellikle de Alevilik Bektaşilik konusuna ağırlık verilmiştir. Bu durum, programın hazırlanması sürecinde, Avrupa İnsan Hakları Mahkemesi tarafından zorunlu din dersi aleyhine verilmiş kararlar ve bunların dayandığı gerekçelerin de dikkate alındığını göstermektedir.

Öğretim programında Yesevilik, Kadirilik, Mevlevilik, Nakşibendilik ve Alevilik Bektaşilik gibi tasavvufi yorumların kültürümüz içerisindeki önemine ve etkinliğine vurgu yapılmış olması (IDKAB Dersi Öğretim Programı, s. 35) kültürlerarası din eğitimi açısından olumlu bir durumdur. Zira bu yaklaşım, farklı yorumları benimseyen öğrencilerin din derslerinde kendilerini iyi hissetmelerine ve birbirlerini anlayışla karşılamalarına katkı sağlayabilir. Ancak DKAB dersinde İslam içi oluşumlara yer verilirken belirli ilkeler göz önünde bulundurulmazsa, toplumsal bütünlüğümüzün bundan ciddi şekilde zarar göreceği gerçeğinin de unutulmaması gerekir. Bu bakımdan söz konusu meseleye çözüm üretilirken bilimsel yaklaşımın esas alınması, dini hassasiyetlerin gözetilmesi ve toplumsal gerçekliklerimizle çelişmemeye özen gösterilmesi elzemdir.

\section{Sonuç ve Öneriler}

Cumhuriyet dönemi boyunca ülkemizde en fazla tartşşlan meselelerden biri din eğitimi hizmetleri olmuştur. Yönü batıya dönük, aklı ve bilimi esas alan seküler bir ulus devlet inşa etme hedefiyle çıkılan yolda din-devlet ilişkileri bir türlü sağlıklı bir zemine oturtulamamıştır. Bu durum tek parti döneminde din derslerinin kaldırılması, İmam Hatip Okullarının ve İlahiyat Fakültesi'nin kapatılması şeklinde kendini göstermiştir. Çok partili döneme geçişle birlikte din eğitimi alanında olumlu sayılabilecek birtakım düzenlemeler yapılmıştır. Ancak bilimsel yaklaşım esas alınarak yapılmadığı için bu düzenlemeler hem arzu edilen sonuçları vermemiş hem de toplumun belirli kesimlerinde rahatsızlık meydana getirmiştir.

Din eğitimi alanında yapılan düzenlemeler arasında üzerinde en çok tartışılanı, 1982 Anayasası ile din dersinin zorunlu hale getirilmesi olmuştur. Halkımızın bir kesimi çeşitli faktörlerin etkisiyle zorunlu din dersi uygulamasından rahatsızlık duymuştur. Bu rahatsızlık onların bir kısmını zorunlu din dersinden muafiyet için ulusal ve uluslararası mahkemelere başvuruda bulunmaya yöneltmiştir. Öğretim programında zaman zaman güncellemeler yapılması, söz konusu rahatsızlığın giderilmesini sağlamamıştır. Nitekim zorunlu din dersi uygulamasına yönelik itirazlar çeşitli platformlarda güçlü 
şekilde dile getirilmeye devam etmektedir. $\mathrm{Bu}$ itirazların tümünün haklı nedenlerden kaynaklandığını iddia etmek ne kadar yanlış ise hiçbirinin sağlam bir mesnede dayanmadığını iddia etmek de o kadar yanlıştır. Genelleyici yaklaşımdan ve önyargıdan uzak şekilde ele alınmaması halinde söz konusu soruna kalıcı çözüm üretilmesi mümkün olmayacaktır. Bu durum zorunlu din dersi uygulamasına yönelik itirazların akademik çalışmalara konu edilmesinin önemini göstermektedir.

Çocuklarının zorunlu din dersinden muaf tutulması talebiyle ulusal ve uluslararası mahkemelere müracaatta bulunan vatandaşlarımız, zorunlu din derslerinde toplumdaki dinsel çeşitliliğin göz ardı edildiğini, öğrencilere İslam'ın belirli bir anlayışının benimsetilmeye çalışıldığını; nesnellik ve tarafsızlık ilkelerinin gözetilmediğini iddia etmektedirler. Bu iddiaların her biri esasen kültürlerarası din eğitimi yaklaşımı ile yakından ilişkilidir. Zira din derslerinin çoğulcu, tarafsız ve nesnel yaklaşım temelinde işlenmesi için gerekli tedbirlerin alınması, kültürlerarası din eğitiminin de öncelikleri arasındadır.

Bu çalışma, halen yürürlükte olan İDKAB Dersi Öğretim Programı'nın kültürlerarası din eğitimi açısından değerlendirilmesi amacıyla yapılmıştır. Araştırma sürecinde elde edilen veriler, öğretim programının genel hedefleri ile vizyonunun kültürlerarası din eğitimi yaklaşımıyla gayet uyumlu olduğunu göstermektedir. Ancak genel amaçlar ile vizyonun ünite kazanımlarına ve içeriğine yeterince yansımadığı görülmüştür. Programda İslam dışındaki dinlerin tanıtıldığı müstakil bir üniteye rastlanmamıştır. İslam düşüncesindeki yorum farklılıklarını tanıtıcı nitelikte bilgilere ise sadece tek bir ünitenin ayrıldığı tespit edilmiştir. Öğretim programında kültürlerarası din eğitimi açısından ehemmiyet arz eden birçok ünite yer almasına rağmen bu ünitelerin işlenişinde farklı dini geleneklere yer verilip verilmeyeceği meselesinin netliğe kavuşturulmadığı görülmüştür. Öğretim programında konuların, günlük hayattan ve öğrencilerin somut deneyimlerinden hareketle işleneceğinin belirtilmiş olmasından hareketle örtük şekilde de olsa farklı dini geleneklerin derse taşınmasına kapı aralandığı iddia edilebilir. Ancak bu iddia doğru kabul edilse dahi öğretim programında söz konusu durumun din dersi öğretmenlerinin kafa karışıklığı yaşamalarına mahal bırakmayacak netlikte ifade edilmemiş olması kanaatimizce önemli bir eksikliktir.

İDKAB Dersi Öğretim Programı'nda toplumun genelinin üzerinde uzlaşacağı kök değerlerin ön plana çıkarılmış olması, toplumun farklı kesimleri açısından hassasiyet arz eden meselelerde ise normatif ifadelere yer verilmeyip betimleyici bir dilin tercih edilmiş olması kültürlerarası din eğitimi açısından gayet olumludur. Ancak programın toplumsal bir gerçeklik olan dini farklılıkları tanıtma yeterliğine yeterince sahip olduğu söylenemez. Programın mezhepler arası yaklaşım değil de mezhepler üstü yaklaşım esas alınarak hazırlanmış olması kanaatimizce bu duruma yol açan en temel etkendir.

Yapılan incelemede İDKAB Dersi Öğretim Programı́nda ötekileştirici/ayrıştırıcı ifadelere, dinin belirli bir yorumunu ön plana çıkarıp yüceltme gibi bir maksatla hazırlandı̆̆ı iddiasını destekleyebilecek unsurlara rastlanmamıştır. Ancak programın, kültürlerarası din eğitiminde yeri büyük olan eleştirel/sorgulayıcı düşünceyi temele alarak hazırlandığı da söylenemez. Öğrencilerin günümüzde hemen her konuya dair -doğru, yanlış, eksik ya da çarpıtılmış- bilgiye bir tık uzakta oldukları açıtır. Bu durum, DKAB dersinin eleştirel/sorgulayıcı düşüncenin gelişimine katkı sağlayıcı nitelikte olmasının önemini göstermektedir.

Öğretim programında sure ve duaları ezberlemeleri, dini patikleri yerine getirmeleri için öğrencilerin zorlanmayacaklarının belirtilmiş olması kültürlerarası din eğitimi yaklaşımı açısından olumlu bir durumdur. Namazla ilgili konuların öğretiminde ihtiyaç duyulması halinde mezheplerin farklı görüşlerine yer verilebileceğinin vurgulanmış olması için de aynı şeyi söylemek mümkündür. Ne var ki söz konusu durumun niçin sadece namaz ibadeti ile sınırlandırıldığı hususuna programda açıklık getirilmemiştir.

Aynı toplumda yaşayan ama farklı dinlere mensup olan bireylerin birbirlerini tanımalarını ve birbirleriyle sağlıklı ilişkiler kurmalarını sağlamak amacıyla öğretim programlarında gerekli 
düzenlemelerin yapılması kimsenin karşı çıkacağı bir durum değildir. Ancak bu amaca ulaşmanın en isabetli yolu, hakikatin tek kaynağının ve kurtuluşun tek yolunun kendi dinleri olduğu inancından bireyleri vazgeçirmek değil, insanların farklılıklara saygı duymasını sağlamaktır. Farklı dinlere ya da din anlayışlarına sahip bireylerin bir arada barış içerisinde yaşamaları amaçlanıyorsa, İslam dininin temel kaynaklarında buna katkı sağlayacak veriler zaten yeterince mevcuttur. Bu verilere öğretim programında yer vererek zorunlu din dersinde farklılıklara saygı temelinde din eğitimi hizmeti verilmesi pekâlâ mümkündür.

Amaçları açısından değerlendirilecek olursa kültürlerarası din eğitiminin, farklılıkların bir arada yaşadığı modern toplumların kayıtsız kalamayacağı bir yaklaşım olduğu rahatlıkla söylenebilir. Ancak bu amaçlara ulaşılması için ortaya konulan ilkeler ve önerilen din eğitimi modelleri söz konusu olduğunda onun her toplum yapısına ve her kademedeki öğrencilere uygun bir yaklaşım olduğu söylenemez. Toplumların kendi gerçekliklerini yok sayarak farklı toplumlarda uygulanan kültürlerarası din eğitimi modellerini aynen uygulamaları, benzer sonuçları kendilerinin de alacağı anlamına gelmez. Çünkü her toplumun kültürel yapısı, sorunları, ihtiyaçları, riskleri, avantajları vs. farklıdır. Bir toplum için ideal denilebilecek bir din eğitimi modeli bir başka toplum için sorun kaynağı olabilir. Bu bakımdan kültürlerarası din eğitiminin ve bu kapsamda geliştirilen din eğitimi modellerinin eleștirel yaklaşımla ele alınması, avantajlarından yararlanıp dezavantajlarından korunmayı sağlayacak stratejiler geliştirilmesi kanaatimizce en isabetli yol olacaktır.

\section{Yazar Katkı Oranları}

Çalışmaya, 1. yazar \%50, 2. yazar \%50 oranında katkı sağlamıştır.

\section{Kaynakça}

Altaş, N. (2003). Çokkültürlülük ve Din Eğitimi. Ankara: Nobel Yayıncılık.

Altaş, N. (2003). Çokkültürlü Din Eğitimi Modeli Geliştirmede İşlem Basamakları İçin Bir Deneme. Değerler Ĕ̆itimi Dergisi, 1(1), 19-42.

Ayas, M. (2020). Kültürlerarası Din Eğitimi ve Çoğulculuk. Din Eğitimi. Ed. M. Fatih Genç, İstanbul: Lisans Yayıncılık.

Aydın, M. Ș. (2008). Bir Din Eğitimi Kurumu Olarak Kur'an Kursu. Ankara: DỉB Yayınları.

Aydın, M. Ş. (2009). Din Eğitimi İçin Yeni Paradigma İhtiyacı. IV. Din Şurası Tebliğ ve Müzakereleri, Ankara: DİB Yayınları.

Aydın, M. Ş. (2011a). Açık Toplumda Din Eğitimi. Ankara: Nobel Akademi Yayıncılık.

Aydın, M. Ş. (2011b). Din Öğretiminde Öğrenci Merkezlilik. Diyanet Aylık Dergi, 46, 26-29.

Aydın, M. Ş. (2019). Din Eğitimi Bilimi. Kayseri: Kimlik Yayınları.

Aydın, M. Ş. ve Osmanoğlu, C. (2015). Kültürlerarası Din Eğitimi, Ankara: Nobel Yayıncılık.

Bayrakdar, N., Denizer, N., Avcl, M. ve Saygilı, S. (2017). Disiplinlerarası Bir Yaklaşımla Dinsel Şüphe Problemi. Ankara: Pegem Akademi Yayıncllık.

Cırık, İ. (2008). Çok Kültürlü Eğitim ve Yansımaları. Hacettepe Üniversitesi Eğitim Fakültesi Dergisi, 34, 27-40.

Coşkun, H. (2016). Kültürlerarası Eğitim Türkiye ve Almanya Örneği. Ankara: Conrad Adenauer Stiftung.

Demirel, Ö. (2010). Eğitimde Program Geliştirme. Ankara: Pegem Yayınları.

Diyanet İşleri Başkanlığı (2014). Türkiye'de Dini Hayat Araştırması. Ankara: Diyanet İşleri Başkanlığı.

Erken, B. (2020). Hukuki Temelde Türkiye'de Zorunlu Din Dersi. Selçuk Üniversitesi Hukuk Fakültesi Dergisi, 28(1), 237-263. 
Ev, H. (2010). İlköğretim Din Kültürü ve Ahlak Bilgisi Dersi Öğretim Programı Hakkında Bir Değerlendirme. Dokuz Eylül Üniversitesi İlahiyat Fakültesi Dergisi, 32, 139167.

Kaya, F. (2018). DKAB Derslerinde Aleviliğin Öğretimi ve Sorunları. Türkiye'de Din Eğitimi ve Sorunları. Ed. Mustafa Köylü, İstanbul: Dem Yayınları.

Kaymakcan, R. (2007). Türkiye'de Din Eğitiminde Çoğulculuk ve Yapılandırmacıllk: Yeni Ortaöğretim Din Kültürü Ve Ahlak Bilgisi Programı Bağlamında Bir Değerlendirme. Kuram ve Uygulamada Eğitim Bilimleri Dergisi, 7(1), 177-210.

Kılıç, A. İ. (2019). Eleştirel Düşünmenin Geliştirilmesinde Din Eğitiminin Rolü. İslâm Düşüncesinde Eleștiri Kültürü ve Tahammül Ahlâkı Milletlerarası Tartışmalı İlmî Toplantı (26 - 28 Nisan 2019), Cilt 1, İstanbul: Ensar Neşriyat, 425-442.

Kostova, S. Ç. (2005). Çokkültürlü Eğitim: Bulgaristan Örneği. Kaygı - Uludağ Üniversitesi Felsefe Dergisi, Çev. Emin Atasoy, 12, 217-230.

Köprülü, G. (2019). Uluslararası Hukuk Bağlamında Din ve Vicdan Hürriyetinin Korunması. Necmettin Erbakan Üniversitesi Siyasal Bilgiler Fakültesi Dergisi, 1(1), 80-91.

Küçük, S. (2011). Kültürler Arası Öğrenme Üzerine Bir Kavram-Model Denemesi ve Türkçe Ders Kitapları. Türklük Bilimi Araştırmaları Dergisi, 29, 227-260.

Nayir, F. ve Sarıdaș, G. (2020). Çokkültürlü Eğitim, Kültürlerarası Eğitim ve Kültürel Değerlere Duyarlı Eğitime İlişkin Kavramsal Bir İnceleme. Uluslararası Sosyal Araștırmalar Dergisi, 13(70), 769-779.

Nohl, A. M. (2009). Kültürlerarası Pedagoji. Çev. R. Nazlı Somel, İstanbul: Bilgi Üniversitesi Yayınları.

Oğuzkan, A. F. (1993). Eğitim Terimleri Sözlüğü. Ankara: Emel Matbaacllık.

Okumuş, E. (2016). Toplum Bağlamında Din - Kültür Etkileşimi. Turkish Studies, 11(7), 269-292.

Okumuşlar, M. ve Bilecik, S. (2019). Kültürel Din Pedagojisi. Cumhuriyet Ilahiyat Dergisi, 23(3), 1279-1292.

Öncel, H. (2013). İlköğretim Din Kültürü Ve Ahlak Bilgisi Öğretim Programının Kültürler Arası Din Eğitimi Açısından Değerlendirilmesi (Yayımlanmamış yüksek lisans tezi). Dokuz Eylül Üniversitesi Sosyal Bilimler Enstitüsü, İzmir.

Sancak, S. (2015). Kur'an Perspektifinde Din Eğitiminde Sosyo-Kültürel Farklılıkları Anlamlandırma Sürecinde "Empati" Kavramı. Abant İzzet Baysal Üniversitesi Ilahiyat Fakültesi Dergisi, 3(6), 42-71.

Topcubaşı, T. (2016). Türkiye'de ve Dünyada Kültürlerarası Eğitim. International Journal of Education Technology and Scientific Researches, 1, 34-45.

Tosun, C. (2010). Din Eğitimi Bilimi. Ankara: Pegem Akademi Yayınları.

Tumat, A. J. (1992). Interkulturelle Erziehung als Aufgabe und Chance, in: Die Ministrien für Bildung, Wissenschaft, Kultur und Sport des Landes Schleswig-Holstein (Hrsg.): Lehrplanrevision in Schleswig-Holstein, Kiel.

Turan, İ. (2012). Ulusal ve Uluslararası Hukuk Açısından Türkiye'de Din Eğitiminin Yasal Dayanakları. Ondokuz Mayıs Üniversitesi İlahiyat Fakültesi Dergisi, 32, 77-109.

Yıldırım, A. ve Şimşek, H. (2008). Sosyal Bilimlerde Nitel Araştırma Yöntemleri. Ankara: Seçkin Yayıncılık.

Yörük, T. (2016). Farklı Din Anlayışlarına Ayrılan Yer Açısından Türkiye'de Cumhuriyet Dönemi Din Öğretimi Programları. International Journal of Cultural and Social Studies, 2(1), 305-320. 
Zengin, M. (2011a). Din Eğitimi Ve Öğretiminde Yapılandırmacı Yaklaşım. İstanbul: Değerler Eğitimi Merkezi Yayınları.

Zengin, M. (2017). Cumhuriyet Dönemi Din Dersi Öğretim Programları Ve Ders Kitaplarında Dinler, İnançlar Ve İslam Düşüncesinde Yorumlar. İstanbul: Dem Yayınları.

Zengin, M. A. (2011b). AİHM'nin Hasan ve Eylem Zengin - Türkiye Kararının Değerlendirilmesi. Selçuk Üniversitesi Hukuk Fakültesi Dergisi, 19(2), 41-67.

\section{Extended Abstract}

Religious education is an activity as old as humanity. In the historical process different approaches have emerged in terms of what kind of understanding, for what purposes, by whom, where and how this activity will be carried out. Depending on the various factors under the influence, societies have had to constantly review their approaches to the issue of religious education. Among these factors the most decisive one in the last period has been the risks and needs arising from the phenomenon of globalization.

Especially after the Second World War, there was a serious increase in the proportion of people who migrated from the village to the city on the one hand and from the underdeveloped countries to the developed countries on the other. Again in this period rapid developments in science and technology have revealed new possibilities in the fields of communication and transportation and accordingly the borders between societies, and cultures have almost disappeared (Sancak, 2015; Altas, 2003). The increase in the possibility of encountering and interacting with each other among people whose language, religion, understanding of religion, ideology, political view, understanding of life and lifestyle are different has brought some risks in terms of both human rights, and social peace made it necessary to manage the intercultural interaction process. This obligation has led international institutions and organizations to develop solutions in cooperation with the states' parties and scientists. Here, one of the solutions that has been put forward in this process and which has been the subject of frequent discussion recently has been 'intercultural education' (Aydın \& Osmanoğlu, 2015).

An important part of intercultural education is intercultural religious education because the most dominant element in culture is 'religion'. It is possible to see the influence of religion in almost every part of culture. This is an inevitable consequence of the fact that the formation of cultures is a process that develops under the influence of religion (Okumus, 2016).

Intercultural religious education is the process of gaining intercultural knowledge, skills and attitudes to individuals accompanied by content selected from different religions or different interpretations within religion (Aydın \& Osmanoğlu, 2015). Intercultural religious education requires educational environments where different preferences and opinions in the field of religion are respected and supported cultures are accepted as equal and the majority and minority are ready to understand each other (Öncel, 2013).

This study was carried out in order to evaluate the current Primary Education Religious Culture and Moral Education Curriculum in terms of intercultural religious education. The data obtained during the research process show that the general objectives and vision of the curriculum are very compatible with the intercultural religious education approach. However, it has been observed that the vision with general purposes is not sufficiently reflected in the unit achievements and content.

There was no separate unit in the curriculum in which religions other than Islam were introduced. It has been determined that only a single unit is allocated to the information that introduces the differences in interpretation in Islamic thought. Although there are many units that are important in terms of intercultural religious education in the curriculum, it seems that the issue of whether different religious traditions will be included in the processing of these units has not been clarified. It can be claimed that the door was opened for the transfer of different religious traditions to the lesson, albeit implicitly since it was stated in the curriculum that the subjects would be covered with reference to daily life and the concrete experiences of the students. However, even if this claim is accepted as true, it is an important shortcoming in our opinion that the situation in question was not clearly expressed in the curriculum so that it would not cause confusion for religion lesson teachers. 
It is very positive in terms of intercultural religious education that the root values that the general public will agree on are brought to the fore in the curriculum and that a descriptive language is preferred instead of normative expressions on issues that are sensitive for different segments of the society. However, it cannot be said that the program has the ability to introduce religious differences which is a social reality. The fact that the curriculum was prepared on the basis of a supra-sectarian approach rather than an inter-denominational approach, in our opinion, is the most fundamental factor leading to this situation.

In the curriculum, there were no elements that could support the claim that othering/separating expressions and the claim that it was prepared with the aim of bringing a certain interpretation of religion to the fore and glorifying it. However, it cannot be said that the program was prepared on the basis of critical/inquiring thinking which has a great place in intercultural religious education.

It is understandable that states, which have lost the opportunity to preserve the culturally homogeneous structure of societies turn to the option of intercultural religious education in order to protect social peace and tranquility. However, ignoring the realities of societies and applying the same intercultural religious education models applied in different societies will not mean that they will get similar results. In the field of religious education it is inevitable that the arrangements to be made without considering the social realities will cause serious problems, because the structure of each society, its problems, needs, risks, advantages etc. is different. A religious education model that can be called ideal for one society may be a source of problems for another society. 
